\title{
Idea-Phyrlab Development (Physical Learning Media Based on Virtual Laboratory on Ideal Gas Equation)
}

\author{
Afiq Agung $^{1}$, Nurfaida ${ }^{2}$ \\ Department of Physics Education \\ Universitas Negeri Makassar, Indonesia \\ arsyman@gmail.com
}

\author{
Muhammad Nasrullah ${ }^{3}$ \\ Dept. of Informatics and Computer Engineering Education \\ Universitas Negeri Makassar, Indonesia \\ muhammadnasrullah21@gmail.com
}

\begin{abstract}
Research objectives: (1) To know the process of development of virtual laboratory learning media on ideal gas equation material Class XI, (2) to know the level of feasibility of virtual laboratory physics learning media on ideal gas equation material Class XI. Research using $R$ \& $D$ approach with 3D model. The process of appraising the feasibility of learning media using questionnaires for material experts ( 2 persons), media experts ( 2 persons), field limited field trial respondents in Islamic Senior High School Athirah 1 Kajaolalido (17 students) and broader field test respondents in SMA Islam Athirah 1 Kajaolalido (30 students), SMA Negeri 1 Makassar (30 students), and SMA Negeri 17 Makassar (30 students). The research results were (1) the concept of Ideal Gas Equation material product with the format of virtual laboratory learning media products. After going through the second phase of the design is done development stage, where the first process (expert judgment), there are 6 improvements from expert material advice and 1 improvement from expert media advice. Then the second process (expert appraisal), experienced, (2) improvements from the practitioner to produce the final product called Idea-Phyrlab. The results of the assessment of the material experts get a score average of 3.00 in the eligible category. The results of the assessment of media experts get the average score of 3.79 in the category very feasible. Assessment results from a limited field trial earned a mean score of 3.55 in a very viable category. Based on the data, it can be concluded that the learning media for Ideal Gas Equation material based on virtual laboratory is stated suitable for use in physics learning mater ideal gas equation.
\end{abstract}

Keywords-Curriculum of 2013; Development of Physics Learning Media; Feasibility Level; Idea-Phyrlab; Ideal Gas Equation

\section{INTRODUCTION}

The results of research conducted by Festiyed in 2015 states that the learning process of the field of study in Curriculum 2013 is not optimum, the assessment is not yet sufficient, and the teacher's understanding of the teaching task is still very mechanistic [1]. Scientific learning is a learning that should be applied in implementing the 2013 curriculum [2]. It is known that the scientific study includes five learning activities: observing, asking, experimenting or seeking information, reasoning or associations to process information and develop networks or communicate investigative results.
Scientific learning emphasizes on finding out instead of being told [3].

Practicum is an important requirement in scientific learning, including in the field of physics studies. However, so far not formulated how to make the lab can form learners who are creative and have the skills of the process of science. As in Permendiknas no. 22 of 2006, the learning process emphasizes the provision of direct experience to develop competencies to explore and understand the natural world scientifically. Learning is directed to finding out and doing so that it helps students to gain a deeper experience of the natural world. Practical activities are important in physics learning, because the aspects of products, processes and attitudes of learners can be further developed. Through laboratory activities (experimenting) can train students' scientific attitudes in understanding the concept of learning [4], [5]

Based on research conducted by Khasanah, it was found that one of the obstacles faced by physics teacher of class $\mathrm{X}$ SMA in Yogyakarta City area in utilizing physics practicum in learning process is the availability of practicum tool in limited number [6]. The lack or limitation of practicum tools in a physical laboratory is something that has often been found in high schools in Indonesia. In other words, resolving or solving the problem is not an easy and instant thing but it takes a long time, a lot of effort and money. Thus, it takes a solution that is covering the problem for a while.

In addition to the availability factor and limited number of tools, another constraint is the characteristics of the experiment itself which involves abstract processes and concepts. In reality, the material that discusses the abstract concept can only be conveyed to the learner in the learning process is only theoretical. So an alternative is needed so that experimental activities including abstract concepts can still be done. There are some in physics that describe theoretically in abstract concepts because of the difficulty to put it into practice in the face of the learner. One of the material that has abstract concept is the material of Ideal Gas Cause, because the subject of this material is difficult to observe by naked eye. Therefore, it is deemed necessary to develop a practicum learning medium in order to overcome these problems. 
The development of the world of technology and information is now so rapidly along with the rapid development of science. The growing technology for example computer. There have been many products and benefits gained through the use of computers. One of them in the field of education, where computer technology is often used as one of the learning media. There are many computer technology products that can be used in making learning media such as: Microsoft PowerPoint, adobe flash, digital comics and the latest lector as well as some other applications that can be used online and offline. Practical learning media using a computer with one or more applications is called virtual laboratory.

The researchers offered a practical learning medium related to the ideal gas equation. This learning media is a virtual laboratory assisted in which contains teaching materials and material proof. This is what lies behind the authors lifted the title of research "Idea-Phyrlab Development (Learning Media of Virtual Physics-Based Laboratory on Ideal Gas Equation Material)".

\section{METHODS}

This research is a research development or Research and Development (R \& D). Research and development methods are research methods used to produce a particular product and test the effectiveness of the product [7]. Stages of research used refers to 4D research and development methods developed by Sivasailam Thiagarajan, Dorothy S. Semmel, and Melvyn I. Semmel. This model consists of 4 stages of development, can be seen in Figure 1 below.

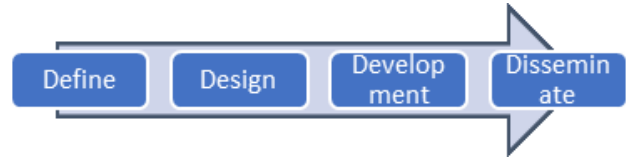

Fig. 1. Development Procedures

\section{A. Development Procedures}

In the early stages of this development research is a Phase Analysis (Analysis). Analysis is done to get information about the needs of instructional media and materials from the subjects to be presented. This analysis is done by observation and interview.

There are several analysis in this phase that is: (1) Analysis of instructional media needs, from the observation and interview conducted in SMAN 1 Makassar which has 4 years applying the curriculum 2013, obtained information that available media related subject of the subject matter does not yet exist. (2) Analysis of the needs and characteristics of learners, learners who study the Ideal Gas Equation is a class XI students who belong to the age group of the age of 17-18 years. According to Jean Piaget's cognitive theory, age 12 is more of an age at the formal operational stage. Age at this stage has the characteristics or behavior of thinking conceptually and hypothetical thinking that can provide a picture, concept, and information as a whole. Learning media that can provide all these needs can be a combination of several components of the media, including text, images, animation, sound, and video. (3) Formulating Subject Competencies, before determining the learning objectives the first thing to do is to define / formulate basic competencies. Basic competencies that are formulated will become a reference for making learning objectives. Basic competence of theoretical learning contained in syllabus of material physics course Ideal Gas Equation in SMA Negeri 1 Makassar Class XI IPA academic year 2016/2017 is "Understanding the Ideal Gas Equation in explaining the characteristics of gas in enclosed spaces". In the syllabus of the material physics course Ideal Gas Equation in SMA Negeri 1 Makassar Class XI IPA year 2016/2017 also there are learning materials that are also used as a consideration for reference making learning purposes.

The Design Stage is the next stage where stage there are also several stages. First, the groove design is used to determine the order of the presentation framework of the learning media material to be created. Second, the interface design stage is a description of the structure of the program or as the initial scheme of the design of making learning media. Interface design is made to facilitate in translating the schematic initial design into the form of programming language. Interface design is based on the flowchart that has been designed.

The Development Stage is the third stage which consists of: (1) Evaluation, at this stage the finished learning media will be evaluated or validated by expert judgment based on existing assessment instruments. Evaluation or validation is done by two experts or expert judgment. The first expert is the material expert and the second expert is the media expert. (2) Revisions, after the evaluation or validation by experts, either from material experts or media experts, then the next process is to make product improvements or revisions. These product improvements or revisions are sourced from validation data already performed by the expert. This product revision or repair is made until it is approved and declared eligible by expert judgment or the experts.

\section{B. Place and Time of Research}

This research was conducted in High School which has implemented Curriculum 2013 in class XI MIA Semester Even in Makassar. Implementation of the research conducted in February s / d June 2017. Because this research raised the material of Ideal Gas Equation where the material in Curriculum 2013 taught in class XI MIA Semester Even. As for the reasons for schools that implement the Curriculum 2013 , because this research is motivated by the implementation of Curriculum 2013. It is supported in the results of previous research which states that the learning process in the field curriculum 2013 is not optimum [1].

\section{Research Subject}

The subject of this study is differentiated into two parts. The first part of the subject is a test of product design or expert test, consisting of media experts and material experts. While the second part is the subject of product testing or expert test and trial usage.

- The subject of a product design test or an expert test, the subject of product design testing or expert test is conducted by 4 persons, 2 material experts and 2 
persons as media experts. The subject of product design testing or expert test is selected who are competent in their respective fields. Material experts are required to validate the product developed in terms of the availability of the product as a learning medium. Meanwhile, material experts are required to validate the physics material contained in the developed learning media.

- First, a limited field trial was conducted in Islamic Senior High School Athirah 1 Kajaolalido, with a total of 17 students. Secondly, trial use with field test responders is more widely implemented in Islamic High School Athirah 1 Kajaolalido (22 students), SMA Negeri 1 Makassar (30 students) and SMA Negeri 17 Makassar (31 students).

\section{Data Collection Methods and Instruments}

The method used to collect data is by using a questionnaire. This questionnaire technique is conducted to evaluate the products that have been developed. Questionnaires will be given to media experts, materials experts, and learners to be able to provide an assessment of the product being developed.

Questionnaire is a data collection technique that is done by giving a set of questions or statements to the respondent to answer [7], [8].

Media experts are people who understand and master the various media used in the media product learning. Research instruments for media experts are reviewed from the following aspects: (1) media benefits, (2) media design and (3) media operation and (4) navigation / operation of the media. These four aspects have often been used in research development of instructional media, for example in research conducted by Suhariyanto, who developed adobe flash based learning media on electrical materials [9] and Ariani who developed basic multimedia teaching materials [10]. Grid instruments used in validating media feasibility in terms of overall display design. Expert material is a person who master or master the material contained in the media product learning. Instruments used by materials and teachers are reviewed from several aspects, namely: (1) syllabus, (2) material quality, (3) presentation of material. Instruments of media application in learning include aspects (1) media benefits, (2) material delivery, (3) syllabus, (4) media design, and (5) media operation.

\section{E. Data Analysis Technique}

Data analysis technique is done using quantitative descriptive analysis technique. This technique is a way of analyzing quantitative data obtained from expert test questionnaire and field test. Quantitative data in the form of numbers of the results of the assessment or measurement can be processed by summed, then compared with the expected number it will get the average value of assessment [11], [12]. Then if the way is described in the formula then it can be written as follows:

$$
\text { average rating }=\frac{\text { total score of assesment result }}{\text { number of apraisers }}
$$

The average scores on the result scores are then converted to a qualitative scale of scale 5 with a Likert scale on the value table conversion table [13]-[15] as follows:

TABLE I. TABLE VALUATION SCALE AND INTERPRETATION.

\begin{tabular}{cl}
\hline Score Interval & \multicolumn{1}{c}{ Category } \\
\hline$X \geq 3,4$ & Very Decent \\
\hline $2,8<X \leq 3,4$ & Decent \\
\hline $2,2<X \leq 2,8$ & Decent Enough \\
\hline $1,6<X \leq 2,2$ & Less Eligible \\
\hline$X \leq 1,6$ & Very Less Worthy \\
\hline & \multicolumn{2}{c}{ a. Table Conversion Value by Sukardio (2005) }
\end{tabular}

Information:

$\mathrm{X} \quad$ : Average Score of Implementation

Maximum Score : 4

Minimum Score : 1

\section{RESULTS AND DISCUSSION}

This learning media is used for students of XI MIA class who apply Curriculum 2013. Field trials have been conducted at schools that have implemented Curriculum 2013 in class XI MIA SMA Negeri 1 Makassar, SMA Negeri 17 Makassar and SMA Islam Athirah 1 Kajaolalido academic year 2016 / 2017. Achievements of these objectives can be described as follows:

\section{A. Learning Media Development Process}

After going through the steps - development steps to produce a product, then generated the product of learning media for the material of Ideal Gas Equation in the subject of physics. This development process begins by finding the potential problems contained in the process of learning Ideal Gas Equations physics subjects. Problems that have been obtained then reviewed and the results of the study found a solution that is required a development of learning products based on virtual laboratory on the material of Ideal Gas Equation. The development of instructional media begins with define phase (Defining) done through initial analysis, curriculum analysis, student analysis, material analysis, and formulate goals. After all steps in the define stage (Defining) is done then the next crop is the design stage design (design). At this stage is to choose the form of presentation of learning, choose the media (program / software) that will be used, and design the initial design of the learning media.

The next activity is to choose the format or form of the presentation of instructional media, the selection of this format is done based on the data that has been obtained at the define stage (Defining). Based on the data from the define stage (Defining) is obtained the appropriate format for learning media is experiment / experiment. This experimental / experimental format was chosen because it focused more on the theoretical or experimental application stage of the theory or in experimental form. As for the format of the content of learning media content material used text, images, animation, and audio. In the activity format used worksheets learners to

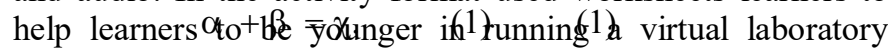
according to learning objectives. 
The result of this initial design stage is a virtual laboratory based learning medium for Ideal Gas Equation material which has three main activities and one additional activity, namely (1) Determine the relation of volume $\mathrm{V}$ to pressure $\mathrm{P}$ in ideal gas, (2) Determine the relationship of temperature $\mathrm{T}$ to pressure $\mathrm{P}$ in the ideal gas, (3) Determine the relation of the number of moles $\mathrm{n}$ to the pressure $\mathrm{P}$ in the ideal gas, and (4) determine the form of Ideal Gas Equation.

Learning media that has been completed is a medium of learning with prototype status results from the initial design. Furthermore, the learning media enter the development stage (development) to produce a final product. At this stage the virtual laboratory-based learning media for Ideal Gas Equation material with prototype status will be validated or assessed by material experts and media experts. Data from the validation results are then used as a reference in the improvement of learning media.

Through the data obtained from the validation of the learning media on the material side has undergone several times improvements such as the use of more specific media names, the addition of arrows in the graph of experimental results, eliminating the exercise menu and using the learner's worksheets, change the sentence "relationship pressure $\mathrm{P}$ against : "To be sentence" influence ... to pressure P ", Appearance of independent variable only as variable whose value is changeable and does not display form of Ideal Gas Equation. In terms of media improvements made include improving the quality of sound / audio from the learning media.

Learning media that have been completed validated by material experts and media experts and has been improved, then entered the stage of field trials and limited field trials more widely. This trial was conducted to determine the feasibility based on the response of learners as prospective users of the product to the learning media for the material of Ideal Gas Equation based on Virtual Laboratory Based on limited test data, it is known that there are still deficiencies in the learning media that the students have difficulty understanding the learning objectives and some computer devices does not have a flash player. To follow-up then made improvements to the learning media that includes (1) Includes flash player in the media folder, and (2) Using Student Worksheet that each activity based on learning indicators. In broader field trials the media results get into the category very feasible after being analyzed and all validators give the option to "ready to propagate according to revision", so that the learning media is ready to become the final product.

\section{B. Feasibility of Media Learning}

The feasibility of learning media for the Ideal Gas Equation material based on Virtual Laboratory is done through assessment or validation by material experts and media experts. Material validation conducted by the material expert includes several aspects, namely the suitability of the learning objectives, the quality of the material, the presentation of material content, and the presentation of self-evaluation. While media validation conducted by media experts include several aspects namely the suitability of media benefits, media design, and navigation / media.

Based on the results of the assessment conducted by the material experts, obtained the result that the learning media for the Ideal Gas Equation material based on Virtual Laboratory get an average valuation of 3.43 which means entering in the appropriate category. The results of the expert material ratings are presented in the following Fig 2.

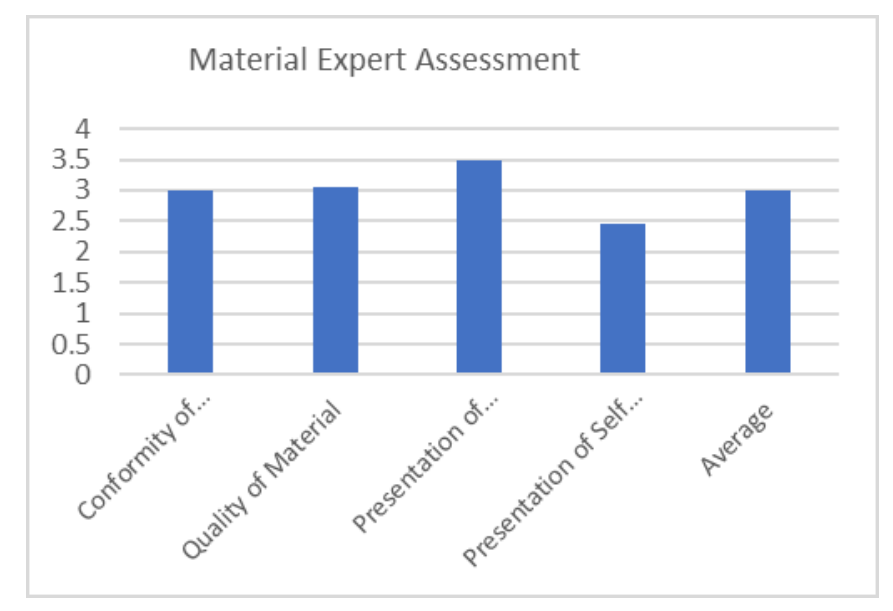

Fig. 2. The Graph of Result Material Expert Assesment

Based on the results of the assessment conducted by media experts, obtained the result that the learning media for the Ideal Gas Equation material based on Virtual Laboratory get an average assessment of 3.79 which means entering in the category very feasible. The results of the assessment of two media experts are presented in the following Fig 3.

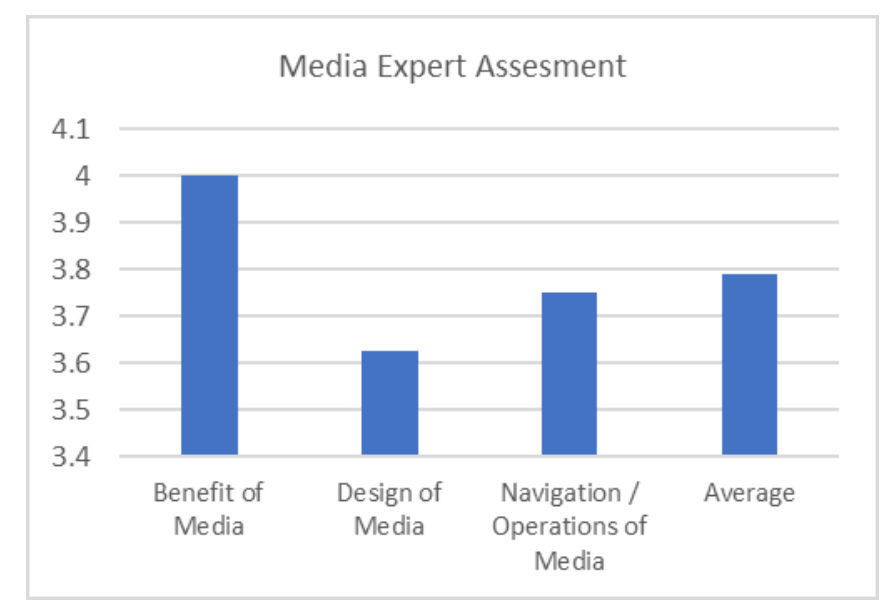

Fig. 3. The Graph of Result Media Expert Assesment

The results of the assessment of mater and media experts are then analyzed cumulatively into one. Based on the data obtained from the cumulative analysis obtained an overall average score of 3.37. The score shows the overall assessment of learning media indicate the appropriate category. A combined scoring result of media experts and material experts is presented in Fig. 4. 


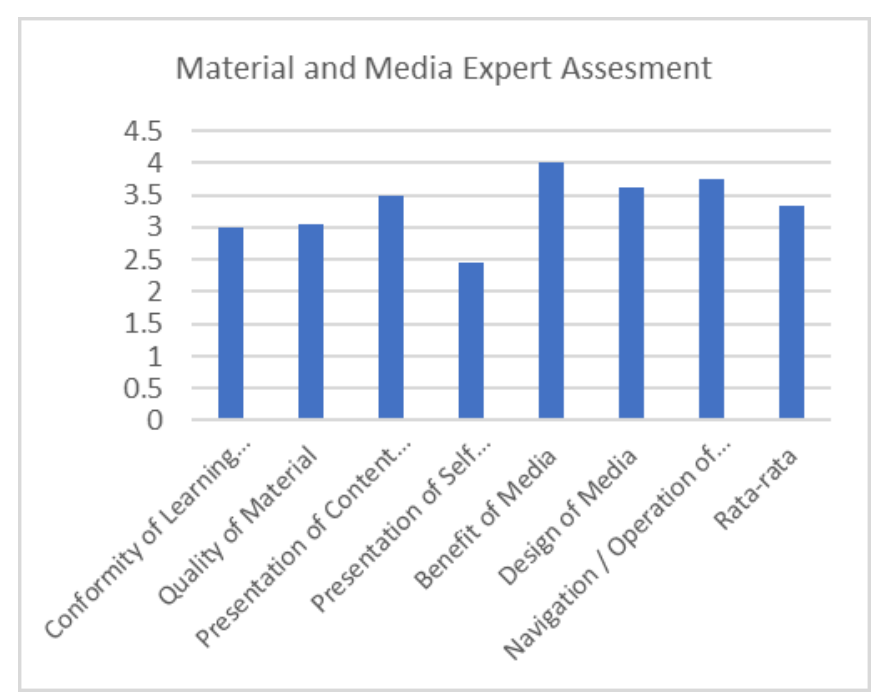

Fig. 4. The Graph of Result Material and Media Expert Assesment

Fig 4 shows that the highest average score is in the media benefit aspect of 4.00 which falls into the very feasible category. Second is the aspect of navigation / media mediation with an average score of 3.75 which is included in the category is very feasible. The third is the aspect of media design with an average score of 3,625 which falls into the very feasible category. The score shows the overall assessment of learning media indicate the appropriate category.

In the field trial phase there were two trials: limited field trials and wider field trials. The purpose of field trials is to obtain data in the form of responses from learners and teachers / educators as potential users of multi-media learning for the material of Ideal Gas Equation based on Virtual Laboratory. Aspects assessed to determine the response of learners include aspects of media benefits, aspects of delivery of material content, suitability of learning objectives, media design, and navigation / media.

A limited field trial used respondents from students of class XI MIA 1 in Athirah 1 Kajaolalido High School with a total of 17 students. Respondent learners are then asked to provide responses or responses to learning media for Ideal Gas Equation material based on Virtual Laboratory by filling the existing instruments. The average score of limited field trial results is presented in the following Fig 5.

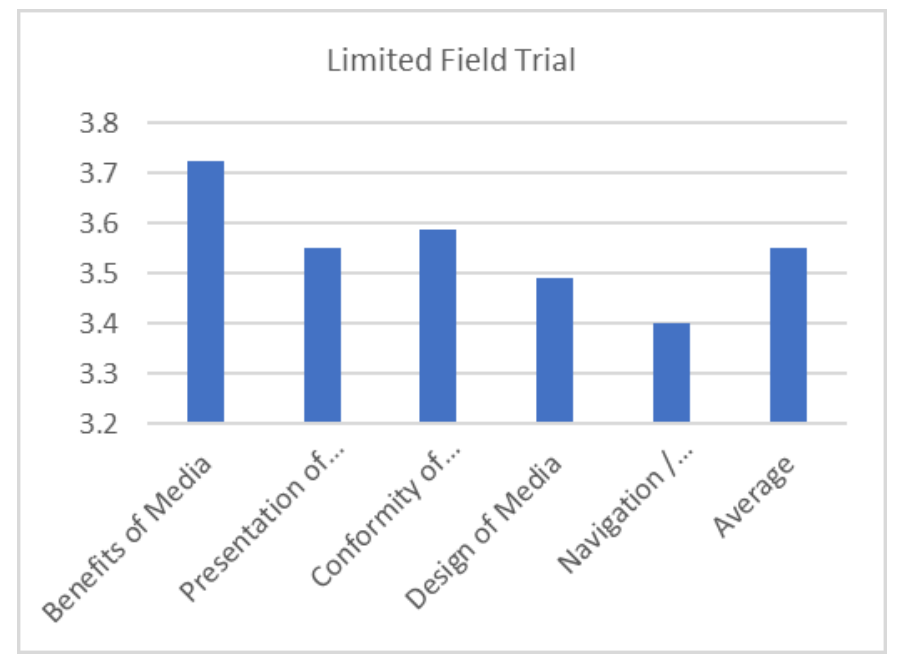

Fig. 5. The Graph of Result Limited Field Trial

Based on the results of responses (responses) on field trials, the results obtained that the learning media for the Ideal Gas Equation material based on Virtual Laboratory is ready or feasible to do a broader field trial with more respondents.

Wider field trials used respondents from XI MIA 1st grade students at Athirah 1 Kajaolalido High School, XI MIA 4 classes in SMA Negeri 1 Makassar and XI MIA 6 classes in SMA Negeri 17 Makassar.

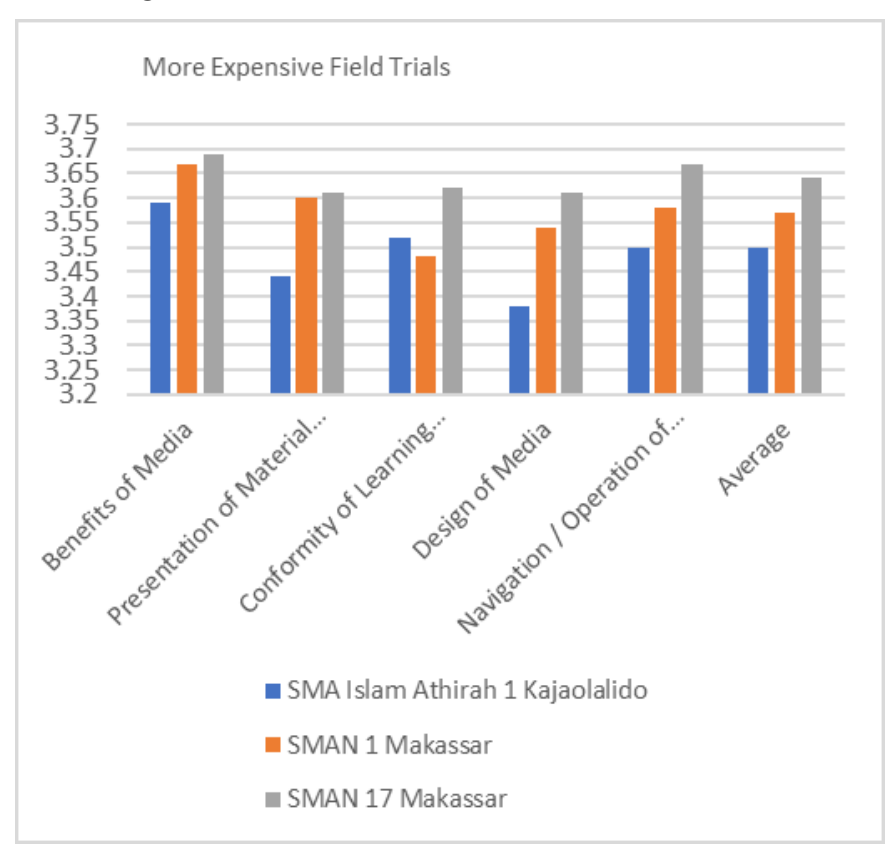

Fig. 6. The Graph of More Expensive Field Trials

Based on the results of responses on a broader field trial of learning media for Ideal Gas Equation material based on Virtual Laboratory, obtained the result that the learning media for the material of Ideal Gas Equations based on Virtual Laboratory get an average rating of 3.57 which means the quality of media the learning goes to the very feasible category. This shows that the learning media for Ideal Gas Equation 
material based on Virtual Laboratory is feasible for use in learning.

\section{CONCLUSION}

Based on the results of research and discussion it can be concluded that product format was a virtual laboratory learning media with the presentation of experiments. The highest aspect of the product was the Media Benefit aspect. From the assessment results from two material experts get the average score of 3.00 (feasible). The results of the assessment from the media expert were get the average score of 3.79 (very feasible). Assessment results from a limited field trial earned a mean score of 3.55 (very feasible). Assessment results from a wider field trial earned a mean score of 3.57 (very feasible). Based on the data, it can be concluded that the learning media for Ideal Gas Equation material based on virtual laboratory was suitable to be used in physics learning mater ideal gas equation.

\section{REFERENCES}

[1] Festiyed, "Collection of Evaluation Material. Introduction Study of Curriculum 2013 Implementation in Integrating the Scientific Approach through Inkuiri Model and Authentic Assessment in Science Lesson in Padang City.," Universitas Negeri Padang, 2015.

[2] R. A. Sani, Scientific Learning for the Implementation of Curriculum 2013. Jakarta: Bumi Aksara, 2014.

[3] Kemendikbud, "Physical Learning through the Scientific Approach.. Jakarta: Directorate of High School Development Directorate General of Secondary Education Ministry of Education and Culture." Jakarta, 2014.

[4] A. Samsudin, E. Suhendi, R. Efendi, and A. Suhandi, "Development of 'Cells' in Basic Physical Experiments to Develop Performance Skills and Improve Student Motivation.," J. Pendidik. Fis. Indones., vol. 8, no. 1, pp. 15-25, 2012.

[5] C. T. Scholar, "Understanding practical engagement: Perspectives of undergraduate civil engineering students who actively engage with laboratory practicals," vol. 5, no. 1, pp. 47-59, 2015.

[6] N. Khasanah, "Study of Completeness and Utilization of Physics Practicum Tool of X Class of SMA as Implementation of Education Unit Level Curriculum in Yogyakarta City." Yogyakarta, 2013.

[7] Sugiyono, Educational Research Methods. Bandung: CV. Alfabeta, 2012.

[8] D. E. Polkinghorne, "Language and meaning: Data Collection in qualitative research,” J. Counceling Psychol., vol. 52, no. 2, pp. 137$145,2005$.

[9] D. Suhariyanto, "Development of Adobe Flash-Based Learning Media on Electronic Spark Advancer (ESA) Material in Automotive Electrical Subjects Department of Light Vehicle Engineering at SMK N 1 Sedayu.," Universitas Negeri Yogyakarta, Yogyakarta, 2016.

[10] N. W. Ariani, "Development of Multimedia Learning Basic Module for Material Flow Production Process Multimedia Product Class X Multimedia Skills Program at SMK Muh 1 Sleman," Universitas Negeri Yogyakarta, Yogyakarta, 2016.

[11] Arikunto, Research Procedure. Jakarta: PT. Rineka Cipta, 2010.

[12] C. S. Jacelon and K. K. O’Dell, Analyzing qualitative data., vol. 25, no. 3. 2005.

[13] Sukardjo, "Collection of Evaluation Material," Universitas Negeri Yogyakarta, Yogyakarta, 2005.

[14] G. Norman, "Likert scales, levels of measurement and the 'laws' of statistics," Adv. Heal. Sci. Educ., vol. 15, no. 5, pp. 625-632, 2010.

[15] J. A. Gliem and R. R. Gliem, "Calculating, Interpreting, And Reporting Cronbach's Alpha Reliability Coefficient For Likert-Type Scales," no. 1992, pp. 82-88, 2003. 